\title{
Entre o Poder e a Dor: representações sociais da corrupção e violência no Sistema Penitenciário de São Paulo
}

\author{
Marisol de Paula Reis \\ Orientador: Maria Stela Grossi Porto \\ Tese de Doutorado \\ Data da defesa: 28.02.2012
}

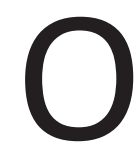

título deste trabalho, Entre o Poder e a Dor, resume a essência do olhar que se lançou à questão da corrupção e da violência no Sistema Penitenciário de São Paulo. A partir da perspectiva do ator principal, o exAgente de Segurança Penitenciária (ex-ASP), e de suas representações sociais, buscou-se trazer à tona os elementos explicativos (materiais e simbólicos) que conferem sentido à suas ações sociais. O estudo teve como lócus de pesquisa o Centro de Progressão Penitenciária de São Miguel Paulista (CPP de São Miguel Paulista) e a Penitenciária "Dr. José Augusto Cesar Salgado" (Penitenciária II de Tremembé).

No âmbito dessa discussão, buscou-se responder às seguintes indagações: 0 que pensam ASPs e ex-ASPs sobre a prática da corrupção exercida entre agentes institucionais e alguns presos no interior dos estabelecimentos penitenciários de São Paulo? Quais as representações para tal conduta dos ex-ASPs? Como essas representações explicam a inserção de alguns agentes penitenciários na atividade ilegal pela via da corrupção? Até que ponto a crença dos ASPs na impunidade do ato constitui-se em elemento importante para se pensar a relação entre a corrupção e a violência nas prisões?

A partir dessas questões, pretendeu-se discutir: 1) a constituição do trabalho dos agentes penitenciários, marcados pelo cumprimento da segurança penitenciária, razão pela qual encontram-se, cotidianamente, em contato direto com os presos; 2) o papel dos agentes penitenciários no campo da promoção e das garantias dos direitos humanos, conquanto pertencentes ao sistema de justiça criminal; 3) a relação entre a corrupção e a violência interpessoal e intramuros; 4) a constituição da identidade social dos ex-ASPs que se encontram presos pela prática do crime de corrupção passiva. 
Tendo como eixo guia as representações sociais dos ex-ASPs, constatou-se que a corrupção é um componente importante das relações estabelecidas entre ASP's e presos e pode, nesse sentido, ser responsável pela concretização de atos/ ações de violência intramuros; o estudo também constatou que a violência é parte constituinte da realidade prisional e, sendo assim, se concretiza por meio da corrupção, mas, também, na ausência dela. Finalmente, a tese indaga sobre os efeitos do encarceramento na constituição da identidade social.

Palavras-chaves: Ex-ASP, Prisão, Corrupção, Violência, Impunidade, Identidade Social, Representações Sociais. 